\title{
Eropanisasi 'Eksternal' dalam Kebijakan Sistem Verifikasi Legalitas Kayu (SVLK) di Indonesia
}

\author{
Andi Akhmad Basith \\ Program Studi Hubungan Internasional, Universitas Diponegoro \\ Jl. Prof. Soedarto, Tembalang, Indonesia 50275 \\ akhmad.basith.dir@gmail.com \\ Submitted: 19 July 2015, Accepted: 12 August 2015
}

\begin{abstract}
The establishment of Indonesian timber verification system, which was started by VPA negotiations in 2007, is followed by the signing and ratification of the agreement leading to the inception of a national timber regime thereafter. It can be seen as a positive effort in tackling illegal trade in timber and illegal logging in Indonesia. Nevertheless, the study about the creation of Indonesian timber regime should not be separated from the role of the European Union (EU) as the actor contributes greatly in introducing and developing the regime in Indonesia. From a unique standpoint, the establishment of the regime in Indonesia can be seen as EU's success in bringing and implementing EU's timber standards to the outward area, which is in essence, not within its sovereign territory and legal jurisdiction. This study aims to assess the extent to which the EU is involved in influencing and affecting the creation of Indonesian timber regulation of SVLK in Indonesia.
\end{abstract}

Keywords: Timber, SVLK, Indonesia, European Union (EU)

\begin{abstract}
Abstrak
Pembentukan sistem verifikasi kayu di Indonesia yang diawali dengan negosiasi VPA pada tahun 2007, telah diikuti dengan penandatanganan dan ratifikasi sebuah perjanjian yang menjadi sebuah permulaan lahirnya regim perkayuan nasional. Hal ini dapat dilihat sebagai usaha positif untuk menanggulangi penjualan kayu secara ilegal ataupun penyelundupan kayu di Indonesia. Namun, studi tentang pembentukan regim perkayuan Indonesia ini tidak dapat dipisahkan dengan peran Uni Eropa sebagai aktor yang berkontribusi dalam memperkenalkan dan mengembangkan regim tersebut di Indonesia. Dari sudut pandang yang berbeda, pembentukan regim di Indonesia dapat dilihat dari kesuksesan Uni Eropa dalam membawa dan mengimplentasikan standar kayu untuk teritori eksternal yang sejatinya tidak berada dalam wilayah kedaulatan mereka. Penelitian ini bertujuan untuk mengetahui apakah Uni Eropa terlibat dalam mempengauhi dan memberikan dampak pada pembentukan peraturaan SVLK di Indonesia. Kata Kunci: timber, SVLK, Indonesia, European Union (EU)
\end{abstract}

\section{PENDAHULUAN}

Uni Eropa (UE) merupakan salah satu aktor global yang berkomitmen dalam penanganan isu lingkungan dan pelestarian hutan. Salah satu dimensi utama dalam aspek lingkungan yang mendapat perhatian besar dari UE adalah kejahatan transnasional penyelundupan kayu (illegal logging) yang marak terjadi di negara-negara penghasil dan pengekspor kayu di berbagai belahan dunia. Aktivitas penyelundupan kayu mendapat prioritas khusus dari UE mengingat sifatnya sebagai sebuah kejahatan sistematis yang dapat berimplikasi negatif terhadap misi-misi, nilai dan norma yang coba diperkenalkan dan dibangun oleh UE di seluruh dunia (Communication from the Commission to the Council and the European Parliament, 2013).

Komitmen UE dalam memerangi penyelundupan kayu diwujudkan melalui penerbitan Action Plan bertemakan Forest Law Enforcement, Governance and Trade (FLEGT) pada bulan Mei 2003. FLEGT merupakan dokumen komprehensif yang disusun 
untuk memberikan UE pedoman dan perencanaan strategis dalam menghentikan praktek-praktek perdagangan kayu ilegal. Pedoman dan rencana strategis tersebut berfokus pada lima bidang utama, yakni: 1) kerjasama antar negara; 2) panduan perdagangan kayu dan produk kayu; 3) pengadaan publik; 4) pelibatan sektor swasta dan 5) pelibatan sektor investasi dan perbankan (Communication from the Commission to the Council and the European Parliament, 2013).

Sebagai tindak lanjut pengimplementasian lima bidang utama di atas, UE mendesain perjanjian bilateral Voluntary Partnership Agreement (VPA) melalui keputusan European Council pada tahun 2005 (Beckett, 2005), yang disempurnakan pada tahun 2008 (DIMAS, 2008). Perjanjian ini ditujukan pada Negara-negara pengekspor kayu ke pasar Eropa termasuk Indonesia. Perjanjian VPA mengikat secara hukum dan didesain oleh otoritas UE untuk menghasilkansistem legislasi perkayuan nasional (dikenal sebagai Legality Assurance System - LAS) di masing-masing negara partisipan VPA. LAS berfungsi sebagai rujukan standardisasi untuk memastikan produk kayu yang diekspor oleh negara partisipan VPA ke pasar UE telah diperoleh melalui mekanisme dan tata cara yang legal. Di Indonesia, LAS dikenal sebagai Sistem Verifikasi Legalitas Kayu (SVLK) yang diadopsi oleh pemerintah sejak tahun 2009.

Fenomena pembentukan rezim kayu melalui LAS di negara-negara dunia ketiga dan SVLK di Indonesia, dapat dipandang sebagai sebuah keberhasilan pemerintah UE dalam membawa dan menerapkan standar regulasi perkayuan mereka ke teritori eksternal yang sejatinya tidak berada dalam wilayah kedaulatan mereka. Berangkat dari persepsi tersebut, tulisan ini bertujuan untuk mengkaji sejauh mana pengaruh UE dalam mendorong terciptanya pembentukan rezim kayu SVLK di Indonesia.Bagian pertama dari tulisan ini merupakan pengantar dan latar belakang. Bagian kedua berfokus pada landasan konseptual mengenai UE dan kekuatan serta posisi strategis yang dimilikinya sebagai aktor global yang memberikan kontribusi terhadap posisi tawar UE dalam mengadvokasi nilai dan norma ke Negara-negara di luar regional Eropa. Bagian ketiga akan mendiskusikan aspek Legality Assurance System (LAS) sebagai elemen utama kerjasama VPA. Bagian keempat akanmenganalisa kontribusi UE terhadap pembangunan rezim perkayuan di Indonesia melalui kerjasama VPA. Bagian kelima merupakan kesimpulan.

Secara umum, UE memiliki reputasi sebagai aktor global yang memiliki keberhasilan dalam membangun hard dan soft power. Hard power UE merujuk pada keberhasilan institusi ini dalam bidang yang bersifat konkrit meliputi ekonomi, politik dan militer. UE dikenal luas sebagai organisasi regional dengan pencapaian integrasi ekonomi terbaik di dunia, serta memiliki pola kerja sama politik tingkat supranasional komprehensif yang mampu menopang keberhasilan kerjasama dalam bidang ekonominya. Secara militer, meskipun belum mencapai keberhasilan yang setara di bidang ekonomi dan politik, UE terus berupaya mengembangkan kapasitasnya dalam bidang pertahanan dan keamanan, membuat aspek ini menjadi salah satu bidang yang terus tumbuh dan berkembang dalam ruang lingkup organisasi UE (Flecthner, 2006).

Keberhasilan dalam membangun hard power kemudian diikuti pula oleh keberhasilan UE dalam membangun soft power.Konsep soft power pertama kali diperkenalkan oleh Joseph Nye yang secara sederhana memaknainya sebagai sebuah kemampuan untuk mendapatkan kebutuhan atau memenuhi kepentingan dengan menggunakan pengaruh yang dimiliki ketimbang dengan menggunakan paksaan atau insentif (Nye, 2004). UE merupakan aktor global dengan kemampuan soft power yang signifikan.Secara umum, UE memiliki pengaruh yang kuat dalam tataran internasional yang selanjutnya memudahkan UE dalam mengadvokasi dan menyebarluaskan nilai dan kebijakan-kebijakan yang diusungnya.

Soft power yang dimiliki oleh UE bersumber dari beberapa factor (Nielsen, 2013, p. 729). Pertama berasal dari kultur dan citra negara-negara anggotanya yang memiliki reputasi dalam bidang pengetahuan, peradaban, pendidikan, teknologi, bahasa dan 
olahraga. Kedua berasal dari keberhasilan UE dalam mentransformasi negara-negara anggotanya; tidak saja dari relasi yang konfliktual menuju harmonisasi di bawah prinsip hukum dan kerjasama tetapi juga dari kemunduran ekonomi dan pembangunan menuju kekayaan dan kesejahteraan. Ketiga, soft power UE terbangun dari keberhasilan organisasi ini dalam menciptakan, mengimplementasikan dan menjaga rekayasa - rekayasa sosial yang dapat berjalan dengan baik dan memiliki manfaat yang luas seperti misalnya praktik penyebaran demokrasi, UE single market, Schengen zone dan Euro zone.

Soft power yang dimiliki oleh UE dalam berbagai bidang memberikan posisi yang strategis dalam membingkai arah dan kebijakan politik internasionalnya.Dengan pengaruhnya yang besar, negara-negara disekitar UE cenderung menerima dan bahkan mengikuti kebijakan- kebijakan yang dicanangkan oleh UE, yang kemudian membuat UE menjadi 'global intervener yang efektif (Nielsen, 2013, p. 734).

Dengan pengaruh dan reputasi yang solid dalam percaturan global, satu hal yang menarik dari UE adalah persistensi organisasi ini untuk tetap mengedepankan nilai-nilai normatif dalam politik luar negerinya. Berbeda dengan aktor global lain yang pada umumnya memanfaatkan hard dan soft power untuk menunjang pencapaian kepentingan luar negerinya, UE cenderung memanfaatkan pengaruhnya yang besar untuk membangun dan menyeberluaskan nilai-nilai kemanusiaan universal - juga dikenal dengan istilah 'Norma Keeropaan' (European Norms) yang terangkum dalam pedoman kebijakan dan keamanan luar negeri UE (CFSP). Pengimplementasian nilai-nilai universal tersebut, oleh UE, diarahkan untuk kepentingan pemberdayaan dimensi eksternal (milieu goal) ketimbang memfokuskannya terbatas pada dialektika kepentingan nasional (possession goal) (Smith, 2003) (Nye, 2004, p. 256). UE berupaya untuk membagi dan menyebarluaskan norma dan nilai yang diusungnya pada negara atau teritori eksternal, bukan dengan tujuan untuk semakin menancapkan kekuatan dan memperbesar pencapaian kepentingan luar negerinya, akan tetapi dengan harapan agar dapat membangun sinergitas sehingga kemajuan dan pencapaian UE dapat mentransformasi negara mitra untuk mencapai kemajuan yang sama.

Meski demikian, konsep pemberdayaan eksternal ini dapat pula dipandang sebagai sebuah aspek integral yang tidak terpisahkan dari strategi politik luar negeri yang sejatinya tetap bermuara pada kepentingan nasional (Laidi, 2008). Dalam perspektif ini, dapat dikatakan bahwa motivasi utama UE dalam menyebarkan Norma Keeropaan tidak lain adalah untuk menjaga garis kebijakan mitra-mitra eksternal agar tetap berada pada posisi dan level yang mampu mengimbangi dan membantu UE dalam mewujudkan misinya di berbagai bidang, khususnya dalam ruang lingkup ekonomi dan perdagangan, perdamaian, lingkungan dan teknologi. Salah satu bidang yang mendapat perhatian dari UE adalah bidang lingkungan. UE mencoba membangun rezim lingkungan yang ideal di negara-negara eksportir kayu dengan memperkenalkan perjanjian VPA. Bagian selanjutnya dari paper ini akan memaparkan mengenai VPA serta aspek-aspek yang meliputinya.

VPA adalah perjanjian kerjasama sukarela yang diinisiasi oleh UE dengan negara-negara ekportir kayu di seluruh dunia. Secara prinsip, VPA adalah kerjasama yang didesain oleh UE untuk memastikan bahwa kayu dan produk kayu yang masuk ke pasar UE telah diperoleh dari cara yang legal. Untuk mewujudkan tujuan ini, sebelum EU menandatangani perjanjian VPA, maka negara partisipan diwajibkan untuk membangun atau menghadirkan sebuah sistem nasional yang mengatur legalitas kayu di negara masingmasing.Negara-negara pengekspor kayu yang menandatangani kerjasama VPA dengan UE wajib menyusun mekanisme standarisasi untuk mengontrol, mengaudit dan memastikan bahwa kayu dan produk kayu yang dihasilkan dan diekspor oleh pelaku usaha kayu mereka diperoleh dari sumber yang legal.Mekanisme standardisasi ini dicapai dengan penyusunan sebuah sistem komprehensif yang dikenal sebagai Legality Assurance System (LAS).Metode dan prosedur yang digunakan dalam penyusunan LAS 
sendiri diserahkan sepenuhnya kepada negara-negara partisipan VPA.

Mengingat kemungkinan LAS yang dibangun oleh setiap negara partisipan akan berbeda-beda, maka untuk dapat diterima sebagai acuan dalam kerjasama VPA, UE mendesain elemen standar yang wajib dipenuhi oleh setiap LAS negara-negara partisipan sebelum VPA dapat resmi disepakati. Untuk dapat menjadi payung regulasi yang ideal, LAS negara-negara partisipan diarahkan untuk berfokus pada setidaknya lima elemen utama (EU FLEGT). Kelima elemen ini secara fungsional dapat dibagi ke dalam dua kelompok.Kelompok pertama berisikan elemenelemen esensial yang berkaitan langsung dengan fungsi penjaminan legalitas kayu. Termasuk dalam kelompok pertama ini adalah: Definisi Legalitas; Mekanisme Legalitas dan Sistem Verifikasi. Selanjutnya, kelompok kedua berisikan elemen pendukung yang berkaitan dengan fungsi kegiatan ekspor kayu ke pasar UE yakni Badan Pemberi Lisensi dan Badan Audit Berkala. LAS yang mampu memenuhi kelima elemen ini secara kolektif diharapkan dapat menjadi instrumen yang efisien untuk memastikan status legalitas kayu dan produk kayu yang akan dijual ke UE.

LAS di Indonesia dikenal dengan Sistem Verifikasi Legalitas Kayu - SVLK.SVLK resmi berlaku setelah diadopsi menjadi regulasi nasional melalui Peraturan Menteri Kehutanan RI Nomor P.38/Menhut-II/2009 tentang Standar dan Pedoman Penilaian Kinerja Pengelolaan Hutan Lestari dan Verifikasi Legalitas Kayu pada Pemegang Izin atau pada Hutan Hak.

\section{PEMBAHASAN}

\section{KONTRIBUSI UE DALAM PEMBANGUNAN REZIM KAYU INDONESIA}

Bagian ini akanmengkaji lebih jauh mengenai keterlibatan UE dalam pembentukan rezim kayu di Indonesia melalui regulasi SVLK.Secara umum, kontribusi UE dalam pembangunan rezim kayu di Indonesia dapat dibagi ke dalam dua peran. Pertama, UE melalui kerjasama VPA, memperkenalkan SVLK yang kemudian menandai hadirnya rezim perkayuan yang baru di Indonesia. Hadirnya SVLK di tahun
2009 mengakhiri rezim perkayuan nasional yang telah hadir di Indonesia sejak beberapa dekade sebelumnya. Kedua, SVLK sendiri, merupakan sebuah regulasi yang proses pembuatannya tidak terlepas dari masukan dan arahan UE. Meski pembuatan dan penyusunan LAS diserahkan kepada negara partisipan VPA, pada kenyataannya, proses pembuatan SVLK di Indonesia berada di bawah arahan UE. Hal ini tercermin dari proses penyusunan SVLK yang secara konsisten dan kontinyu mengakomodasi instruksi dan masukan dari UE, membuat SVLK menjadi sebuah regulasi nasional yang mengadopsi standar dari UE.

\section{SVLK SEBAGAI REZIM PERKAYUAN BARU}

Rezim perkayuan Indonesia telah dibangun sejak tahun 1967 dengan diberlakukannya Undang Undang Nomor 5 tentang Ketentuan-ketentuan Pokok Kehutanan. Pada undang-undang ini, pembahasan mengenai pemanfaatan hasil hutan untuk keperluan industri telah diperkenalkan dalam beberapa regulasi.Secara umum, regulasi ini mengakui potensi hasil hutan sebagai salah satu komoditi yang dapat dimanfaatkan untuk mencapai kesejahteraan melalui pemanfaatannya pada bidang industri dan ekspor (Pasal 3 ayat 2 dan Pasal 6b). Upaya pemanfaatan ini dilakukan oleh pemerintah yang memungkinkan partisipasi pihak ketiga baik BUMN, BUMD, pihak perorangan ataupun pihak-pihak swasta untuk ikut terlibat dalam usaha pemanfaatan tersebut (Pasal 14 ayat 3 dan Pasal 17). Selain untuk pemanfaatan komersial, UU Nomor 5 tahun 1967 juga mengakui hak adat terhadap pemanfaatan hutan yang memungkinkan masyarakat adat untuk memperoleh manfaat ekonomi terhadap hutan yang menjadi bagian dari tempat tinggal mereka (Pasal 17).

Selain mengatur mengenai peluang pemanfaatan hutan, UU kehutanan ini juga mengikutsertakan peraturan mengenai upaya pelestarian dan perlindungan hutan.Dalam regulasi disebutkan bahwa upaya untuk memanfaatkan hutan dan hasil hutan tidak boleh bertentangan dengan asas pelestarian dimana upaya-upaya pelestarian seperti mencegah dan membatasi kerusakan hutan perlu untuk dilakukan 
(Pasal 13 ayat 2 dan Pasal 15 ayat 2). Upaya pelestarian ini menjadi tanggung jawab pihak yang berwenang serta dibantu oleh seluruh masyarakat (Pasal 10 ayat 1 dan Pasal 15 ayat 3.

Untuk mengakomodasi perubahan dalam bidang kehutanan yang semakin masif, UU Nomor 5 tahun 1967 ini kemudian digantikan oleh UU No. 41 tahun 1999 dengan substansi regulasi yang lebih komprehensif ${ }^{1}$. Payung utama regulasi nasional mengenai perkayuan ini kemudian dituangkan kedalam beberapa Peraturan Pemerintah (PP). PP yang paling utama menjadi perpanjangan regulasi dari UU No. 41 adalah PP Nomor 34 tahun 2002 mengenai Tata Hutan dan Penyusunan Rencana Pengelolaan Hutan, Pemanfaatan Hutan dan Penggunaan Kawasan Hutan. Peraturan ini secara spesifik melaksanakan Bab V, VII dan XV dari UU Nomor 41 tahun 1999 mengenai pengelolaan hutan, pengawasan hutan dan sanksi ${ }^{1}$.

PP Nomor 34 tahun 2002 bersama dengan UU Nomor 41 tahun 1999 yang menjadi rujukannya kemudian menjadi landasan utama dalam melaksanakan regulasi perkayuan di Indonesia. PP Nomor 34 tahun 2002 secara umum menyediakan informasi mengenai definisi dan detail pemanfaatan serta aspek perizinan yang meliputi tata cara dan mekanisme teknis dalam memanfaatkan hasil hutan (Pasal 17 - 29 serta pasal 33 - 35). Pada pasal-pasal ini, dijelaskan mengenai jenis - jenis hutan dan dalam bentuk apa saja pemanfaatan dapat dilakukan. Pembahasan mengenai jenis hutan menjadi penting karena bagian ini juga memberikan fondasi dasar dalam mendefinisikan praktek apa saja yang termasuk dalam pemanfaatan kayu sebagai hasil hutan. Praktek tersebut adalah penebangan, pengangkutan, penanaman, pemeliharaan, pengamanan, pengolahan, dan pemasaran hasil (Pasal 29 ayat 1). Aspek lain yang dibahas dalam regulasi ini adalah perizinan yang meliputi informasi umum serta pihak-pihak yang berwenang yang dapat mengeluarkan perizinan tersebut.

Secara keseluruhan, PP Nomor 34 tahun 2002 menyediakan aturan dasar mengenai pemanfaatan hutan yang cukup menyeluruh dan telah melaksanakan perannya untuk memberikan penjelasan yang lebih detail mengenai UU Nomor 41 tahun 1999.Meski demikian, peraturan ini masih menyisakan beberapa regulasi yang belum terwadahi khususnya pada peraturan yang menyangkut upaya pemanfaatan kayu sebagai hasil hutan. Definisi ataupun pedoman legal yang lebih jelas mengenai tata cara pemanfaatan kayu oleh PP Nomor 34 tahun 2002 diserahkan kepada peraturan yang lebih detail yang dibuat oleh Menteri Kehutanan. Dengan desain seperti ini, lahirlah Peraturan Menteri Kehutanan (Permenhut) yang memberikan aturan-aturan teknis pada bidang perkayuan yakni Permenhut Nomor P.55/MENHUTII/2006 tentang Penatausahaan Hasil Hutan yang berasal dari Hutan Negara.

Permenhut Nomor P.55 menyediakan regulasi yang komprehensif terhadap upaya pemanfaatan kayu di Indonesia. Sesuai dengan apa yang menjadi misinya, peraturan ini bertujuan untuk memberikan kepastian hukum dan pedoman bagi pihak-pihak yang melakukan usaha di bidang kehutanan (Pasal 2 ayat 1). Dengan fungsinya tersebut, Permenhut Nomor P.55 dapat dipandang sebagai regulasi yang menyediakan standar dan definisi legalitas terhadap kegiatan usaha dalam bidang perkayuan.Praktek usaha yang tidak sesuai dengan regulasi yang telah ditetapkan dalam Permenhut Nomor P.55 oleh karenanya dapat dianggap tidak sesuai dengan hukum dan bersifat ilegal.

Permenhut Nomor P.55 melanjutkan tradisi regulasi dengan menerangkan jenis-jenis pemanfaatan hutan yang dapat memperoleh perizinan serta subjek atau pelaku yang boleh mendapatkan perizinan (Pasal 1 ayat 4 - 15, 10, 30 - 31). Hadirnya informasi mengenai perizinan mengindikasikan bahwa perizinan menjadi syarat legalitas yang utama dalam bidang usaha perkayuan.Selain menjelaskan mengenai perizinan, Permenhut Nomor P.55 juga menerangkan mengenai definisi jenis - jenis kayu, lokasi penampungan kayu, jenis-jenis dokumen yang dibutuhkan untuk mengesahkan kayu serta pejabat berwenang yang dapat memberi pengesahan (Pasal 1 ayat $26-29,35-37,38-42,48-57)$. Selain 
perizinan, dokumen pengesahan atau surat legalitas menjadi prasayarat penting lainnya untuk memberikan status legal pada produk kayu.

Dari paparan di atas dapat diketahui bahwa sampai dengan tahun 2006, setidaknya terdapat tiga regulasi yang menjadi fondasi utama dalam pelaksanaan bidang usaha perkayuan di Indonesia. Tiga regulasi tersebut adalah UU Nomor 41 tahun 1999 sebagai payung utama peraturan yang kemudian diterangkan lagi oleh peraturan pemerintah dan peraturan pada tingkat menteri yakni PP Nomor 34 tahun 2002 dan Permenhut Nomor P.55.

Hadirnya rezim perkayuan nasional yang digawangi oleh ketiga aturan tersebut di atas tidak serta merta menjamin upaya pelestarian hutan secara maksimal.Hal ini disebabkan oleh masih maraknya praktek pemanfaatan hasil hutan secara ilegal, seperti penebangan liar dan pemanfaatan kayu yang tidak memiliki izin.Penelitian menunjukkan bahwa pembalakan liar dan penyelundupan kayu ilegal menjadi dua penyebab utama terjadinya deforestasi di Indonesia (Obidzinski, 2006), dimana lebih dari 51 juta $\mathrm{m}^{3}$ kayu diperoleh dari pembalakan liar tersebut (Kementerian Lingkungan Hidup RI). Pembalakan liar telah menghilangkan 2\% atau sekitar 1,9 juta hektar hutan Indonesia setiap tahunnya (The World Resources Institute) dengan kerugian pemerintah mencapai Rp30 Triliun atau setara dengan USD 4 Milyar (Kementerian Lingkungan Hidup RI). Angka penggundulan hutan yang sangat tinggi ini berimbas pada reputasi internasional Indonesia sebagai salah satu penyedia hutan hujan tropis terbesar ketiga setelah Brazil dan Kongo. Dengan luas total hutan sebesar 90 juta ha, Indonesia menyumbang 10\% dari total keseluruhan hutan hujan tropis dunia. Namun karena pembalakan liar, sejak tahun 1990 Indonesia telah kehilangan 25\% wilayah hutan ini atau setara dengan 28 juta ha (The World Resources Institute).

Fakta maraknya pembalakan liar dan kasus penyelundupan kayu di Indonesia membuat regulasi perkayuan di Indonesia masih dianggap jauh dari efektif.Banyak pihak menganggap bahwa regulasi yang telah ada belum mampu untuk mengatasi perkembangan kejahatan pada bidang kehutanan yang didominasi oleh penebangan liar dan penjualan kayu ilegal.

Tahun 2003 menjadi masa awal pengembangan sistem verifikasi untuk legalitas kayu dilakukan (Lembaga Ekolabel Indonesia). Upaya ini merupakan kelanjutan dari kerjasama Memorandum of Understanding $(\mathrm{MoU})$ antara pemerintah Indonesia dan Britania Raya dalam menanggulangi deforestasi dan perdagangan kayu ilegal yang telah disepakati pada tahun 2002. LSM internasional the Nature Conservancy (TNC) menjadi aktor utama dalam memimpin upaya pengembangan sistem legalitas dengan mengadakan beberapa workshop dan uji coba dengan berbagai pihak. Workshop dan ujicoba ini kemudian menghasilkan draft sistem legalitas kayu yang pertama yang meliputi pengertian dasar, prinsip indikator dan panduan verifikasi.

Pada akhir tahun 2006, tim workshop berhasil merampungkan Draft Sistem Verifikasi Legalitas Kayu yang diserahkan ke Kemeterian Kehutanan. Selanjutnya pada bulan Januari 2007 draft ini diuji secara publik pada Workshop Final Sistem Verifikasi Legalitas Kayu yang melibatkan 74 institusi dan organisasi. Hasil workshop ini kemudian menghasilkan apa yang menjadi draft final Sistem Verifikasi Legalitas Kayu (SVLK).

Pada awal tahun 2007 draft SVLK diserahkan kepada Kementerian Kehutanan untuk direalisasikan menjadi peraturan resmi. Meski demikian, rancangan regulasi ini terpaksa harus berhenti hanya pada tahapan draft. Faktor utama yang menghambat proses realisasi adalah ketidakhadiran konsep kelembagaan yang jelas yang kemudian membuat beberapa konten SVLK khususnya yang berkaitan dengan aspek hukum menjadi tumpang tindih dengan ekspektasi Kementerian Kehutanan (Down to Earth No 76-77, 2008). Meski Kementerian Kehutanan sejatinya ikut terlibat dalam workshop dan ujicoba penyusunan draft SVLK, terdapat beberapa konten draft yang masih menyisakan perbedaan antara Kementerian Kehutanan dan aktor lain yang terlibat menyusun draft tersebut. Oleh karenanya, hingga pada bulan Januari 
2007, regulasi SVLK sesungguhnya masih bersifat draft yang belum diadopsi menjadi peraturan baku.

Perjalanan draft SVLK untuk menjadi sebuah regulasi formal menemui titik terang setelah pemerintah Indonesia bersedia menjadi partisipan kerjasama VPA yang dicanangkan oleh UE.

Berlangsungnya negosiasi antara pemerintah Indonesia dan UE yang menitikberatkan pada eksistensi dan urgensi LAS sebagai substansi utama dalam memerangi perdagangan kayu ilegal mendorong lahirnya iklim penyegaran yang baru terhadap upaya formalisasi SVLK di Indonesia. Tiga bulan setelah negosiasi VPA perdana antara pemerintah Indonesia dan perwakilan UE, pada bulan Juni tahun 2007, pemerintah Indonesia melalui Kementerian Kehutanan mengeluarkan Surat Keputusan Sekretaris Jenderal Departemen Kehutanan (No. 53/II-KUM/2007) untuk membentuk suatu Tim Ad Hoc yang bertugas untuk mempersiapkan lembaga untuk mengurusi pelaksanaan dan pengimplementasian SVLK. Keputusan untuk membentuk Tim Ad Hoc memperlihatkan semangat untuk memperbaiki cakupan dan konsep SVLK agar dapat menjadi sebuah TLAS yang efektif untuk memberantas perdagangan kayu ilegal.

Pada bulan Juni 2009, SVLK akhirnya resmidiadopsi menjadi regulasi formal melalui Peraturan Menteri Kehutanan RI Nomor P.38/ Menhut-II/2009 tentang Standar dan Pedoman Penilaian Kinerja Pengelolaan Hutan Lestari dan Verifikasi Legalitas Kayu pada Pemegang Izin atau pada Hutan Hak.Bersama dengan SVLK ikut diterbitkan pula peraturan yang menerangkan pedoman pelaksanaan SVLK yakni Peraturan Direktur Jenderal Bina Produksi Kehutanan No.P.6/VI-Set/2009 pada tanggal 15 Juni 2009 mengenai Standar dan Pedoman Penilaian Kinerja Pengelolaan Hutan Produksi Lestari dan Verifikasi Legalitas Kayu (Peraturan Menteri Kehutanan RI Nomor P.38/Menhut-II/2009, Pasal 5). Lahirnya Permenhut P.38/Menhut-II/2009 menandai berakhirnya penantian panjang terhadap implementasi legalisasi SVLK untuk menjadi sebuah peraturan baku.

Implementasi draft SVLK menjadi peraturan resmi pada tahun 2009 dimungkinkan oleh kerangka kerjasama VPA yang dijalin dengan UE. Sebagaimana diketahui, kerjasama ini mensyaratkan negara mitra untuk memiliki TLAS. Pemerintah Indonesia menggunakan draft SVLK yang sejatinya telah lama menunggu proses implementasi untuk menjadi TLAS. Dengan demikian, UE melalui VPA dapat dipandang sebagai fasilitator yang menghadirkan 'tekanan' dan 'momentum' yang memungkinkan proses implementasi dapat terjadi. Dalam kerangka political opportunity structure, kemunculan VPA telah memberikan peluang kepada draft SVLK yang sebelumnya telah meredup selama hampir dua tahun untuk kembali diperhitungkan dan akhirnya diimplementasikan menjadi SVLK resmi melalui peraturan nasional yang sekaligus menandai hadirnya rezim regulasi perkayuan Indonesia yang baru.

Tidak hanya menjadi aktor yang memfasilitasi dan memungkinkan lahirnya SVLK menjadi sebuah regulasi resmi, peran EU dalam regulasi SVLK juga mencakup peran sebagai institusi yang mempengaruhi arah dan konten regulasi SVLK. Bagian selanjutnya akan memaparkan peran dan kontibusi UE dalam mempengaruhi konten SVLK agar dapat mengakomodasi kepentingan regulasi perkayuan UE.

Peran dan pengaruh UE dalam penysusunan SVLK

Pengimplementasian SVLK menjadi sebuah produk hukum kemudian tidak menghentikan upaya penyempurnaan terhadap konten dan cakupan regulasinya. Segera setelah diadopsi menjadi peraturan yang baku, diadakan Joint Expert Meeting (JEM) antara perwakilan pemerintah Indonesia, delegasi UE dan para ahli di bulan September 2009. Meeting ini membahas mengenai kompatibilitas SVLK sebagai TLAS Indonesia terhadap desain umum VPA.Aspek utama yang mendapat perhatian dan diskusi adalah definisi legalitas, mekanisme legalitas, verifikasi, penerbitan lisensi dan pengawasan (Kementerian Kehutanan, 2010). Definisi dan mekanisme legalitas serta verikasi telah dianggap sesuai dengan semangat VAP untuk memastikan status legalitas kayu.Meski demikian aspek pemberian lisensi dan pengawasan pada SVLK sebagai sebuah sistem masih dianggap belum ideal (Kementerian Kehutanan, 2010). 
Konten SVLK kembali menjadi fokus utama pembahasan pada Technical Working Group yang masing-masing diadakan di Jakarta pada bulan Desember 2009 dan Maret 2010 serta di Brussels pada bulan Juni 2010. Pada pertemuan teknis ini, kesiapan konten SVLK sebagai sebuah TLAS tetap menjadi perhatian utama. Oleh karenanya, pembahasan pada ketiga pertemuan di atas berfokus untuk memastikan bahwa SVLK dapat menjadi TLAS yang efektif dalam menghentikan peredaran kayu ilegal. Detail dan konten SVLK khususnya pada aspek definisi, mekanisme dan verifikasi kembali mendapatkan perhatian khusus dari para peserta baik yang berasal dari UE maupun dari Indonesia (Kementerian Kehutanan, 2010).

Di sela pertemuan teknis, pada bulan Mei tahun 2010 diadakan pula pertemuan para ahli (JEM) untuk membahas konten dan tingkat kesesuaian SVLK dengan ekspektasi UE terhadap TLAS (Record of Discussion JEM, 2010). Pada pertemuan ini, diskusi konten SVLK dipusatkan pada mekanisme pengawasan, mekanisme verifikasi dan pemberian lisensi serta rencana pemberlakuan regulasi perkayuan untuk negara anggota UE (Record of Discussion JEM, 2010). Pada mekanisme pengawasan, dibahas mengenai jenis-jenis dan metode pengawasan yang dibutuhkan, baik untuk penyelenggaraan SVLK maupun untuk penyelenggaraan VPA secara general.Dalam pertemuan ini, para ahli juga sepakat untuk menjadikan tanda dan dokumen V - Legal sebagai bukti verifikasi kayu Indonesia (Record of Discussion JEM, 2010). Tanda dan dokumen V - Legal ini akan menjadi bukti legalitas yang berlaku sebelum tanda dan dokumen FLEGT - License yang berasal dari VPA disepakati dan diratifikasi (European External Action Serive, 2013). Persetujuan ini dapat mempermudah pemerintah Indonesia dalam menyongsong rencana pemberlakuan peraturan perundang-undangan kayu UE yang baru untuk negara-negara anggotanya, yang juga dibahas dalam pertemuan ini (Record of Discussion JEM, 2010). Dengan perundang - undangan Due Dilligince, seluruh pelaku usaha di negara-negara UE dituntut untuk mampu menjamin legalitas kayu dan bahan kayu yang mereka gunakan atau perjual belikan di wilayah UE ( European Commission). Dengan tanda dan dokumen V - Legal, produk kayu dari Indonesia dapat memasuki pasar UE dan bebas diperdagangkan di sana.

Konten SVLK Indonesia yang terus mengalami revisi dan perubahan membuat persiapan pemerintah Indonesia menuju penandatangan VPA dianggap semakin matang. Putaran TWG yang terakhir pada bulan April 2011 serta pertemuan delegasi tingkat tinggi antar Indonesia dan UE (SOM) pada bulan yang sama di Jakarta telah sampai pada tahap diskusi mengenai hal-hal yang berhubungan dengan persiapan Indonesia dalam pengimplementasian VPA (Sistem Informasi Legalitas Kayu (SILK), 2012). Selanjutnya pada pertemuan SOM yang kedua disepakati pembentukan Joint Preparatory Committee (JPC) untuk membahas aspek yang lebih mendetail mengenai persiapan penandatangan VPA.Pada bulan Mei 2011, pemerintah Indonesia dan delegasi UE sepakat untuk melakukan pemarafan terhadap draft kerjasama VPA. Pemarafan ini bertujuan untuk memperlihatkan komitmen politik dan persetujuan terhadap konten VPA yang telah bersama-sama dipersiapkan oleh kedua pihak. Hal yang paling penting, pemarafan ini juga sekaligus menunjukkan bahwa kedua pihak telah sepakat bahwa konten SVLK Indonesia telah kompatibel terhadap rancang bangun TLAS dan oleh karenanya dapat diterima menjadi basis regulasi dalam kerjasama VPA.

Setelah melalui beberapa pertemuan dan pemarafan VPA, pemerintah Indonesia berupaya untuk semakin mematangkan konten SVLK agar dapat menjadi basis regulasi yang semakin ideal terhadap VPA nanti.Upaya untuk memperbaiki subtansi SVLK ditempuh dengan merevisi konten SVLK sebanyak dua kali.Revisi yang pertama dilakukan pada bulan Desember 2011 dengan dikeluarkannya Permenhut Nomor P.68/Menhut - II/ 2011 yang merevisi beberapa aspek dari Permenhut P.38.Tujuan revisi ini adalah untuk memberikan kepastian hukum dan teknis yang lebih kuat dan akomodatif terhadap regulasi perkayuan yang telah ada dalam Permenhut P.38 (Peraturan Menteri Kehutanan 
RI Nomor P.68/Menhut - II/2011). Untuk mencapai tujuan tersebut, Permenhut P.68 memperluas cakupan dan konteks hukum Permenhut P.38 pada beberapa aspek yang baru, seperti misalnya dengan memberikan tambahan pengaturan berupa klasifikasi badan usaha baru yang menjadi subjek regulasi (Pasal 4, 4 poin a, b). Selain klasifikasi badan usaha, aspek yang mendapat pengembangan adalah mekanisme regulasi khususnya pada aspek dokumentasi yang mulai memperkenalkan tanda dan dokumen V-Legal (Pasal 12(a,b)). Sistem monitoring kemudian diperluas dengan membuka keran pengawasan terhadap pemantau independen yang kini tidak lagi wajib berlatar belakang kehutanan tetapi boleh berasal dari masyarakat madani dan LSM umum (Pasal 1 ayat 8).

Revisi kedua dilaksanakan pada bulan Desember tahun 2012.Kementerian Kehutanan memutuskan untuk merevisi konten Permenhut P. 68 mengikuti Peraturan Menteri Perdagangan Nomor 64/M - DAG/ PER/10/2012 tentang Ketentuan Ekspor Produk Kehutanan.Poin utama yang lahir dari adanya Permendag ini adalah kewajiban untuk melengkapi ekspor kayu dan produk kayu dengan dokumen V Legal per 1 Januari 2013 (Pasal 15).

Dengan lahirnya Permendag 64, Kementerian Kehutanan merasa perlu menyesuaikan kembali beberapa konten dan regulasi terhadap peraturan baru tersebut, khususnya pada regulasi yang mengatur pembuatan tanda dan dokumen V - Legal.Kementerian Kehutanan oleh karenanya mengeluarkan Permenhut P.45 yang memberikan sejumlah perubahan khususnya pada aspek prosedur pemberian lisensi dengan mendirikan unit lisensi yang lebih komprehensif dan terpadu melalui Sistem Informasi Legalitas Kayu (SILK) (Pasal 12A ayat 3. Di satu sisi, hadirnya SILK merupakan strategi pemerintah untuk mempermudah penyedian sertifikasi legalitas yang dibutuhkan menyusul terbitnya Permendag 64 namun di sisi lain, dapat pula dipandang sebagai langkah praktis untuk menguji sejauh mana kompatibilitas sistem legalitas kayu Indonesia dibawah SILK terhadap regulasi perkayuan UE. Langkah praktis ini menjadi penting mengingat UE pada bulan Oktober 2010 telah menyepakati regulasi perkayuan yang baru untuk negara-negara anggotanya. Seperti yang telah dipaparkan sebelumnya, regulasi yang kemudian dinamai European Union Timber Regulation (EUTR) mensyaratkan Due Dilligince yang dibuktikan dengan sertifikat verifikasi atau legalitas kayu dan produk kayu. Di Indonesia, status legalitas dibuktikan dengan tanda dan dokumen V - Legal sampai perjanjian VPA berkekuatan hukum tetap dan sertifikat FLEGT License resmi digunakan. Dalam pelaksanaan uji coba pemerintah kemudian melakukan shipment test produk kayu bersertifikat V - Legal ke UE. Pada bulan Oktober tahun 2012, para pejabat Kementerian Kehutanan dan Perdagangan melakukan uji pengiriman produk kayu dari pelabuhan Kendal menuju Rotterdam Belanda (Pusat Penelitian dan Pengembangan Hasil Hutan, 2012) (Kompas, 2013). Uji pengiriman ini diikuti oleh beberapa eksportir kayu Indonesia serta beberapa importir yang nantinya akan menunggu hasil pengiriman di UE.

Sejak diberlakukan secara wajib mulai 1 Januari 2013, SVLK telah menjadi mekanisme verifikasi bagi kegiatan pengiriman kayu dan produk kayu ke UE.Meski pada awal pemberlakuannya SVLK melalui $\mathrm{V}$ - Legal dapat dikatakan sukses, upaya evaluasi terhadap SVLK tidak serta merta selesai.Sedari awal sejak diperkenalkan, Kementerian Kehutanan bersama dengan UE tetap meninjau tren praktik SVLK dan mengevaluasi kesiapannya dalam menyongsong pemberlakuan VPA. Oleh karenanya, pada bulan Januari 2013, Kementerian Kehutanan bekerjasama dengan UE melaksanakan lokakarya untuk memastikan kesiapan akhir sistem legalitas kayu Indonesia terhadap kesepakatan VPA (Liu, 2013). Terkait dengan tersebut, diadakan pula evaluasi independen oleh para konsultan dan ahli yang ditunjuk oleh The European Forest Institute (EFI) dan Multi-stakeholderForestry Programme (MFP).Evaluasi ini dilaksanakan untuk mengetahui kesiapan akhir SVLK sebelum VPA disepakati.

Dalam pelaksanaan evaluasi, para ahli dan konsultan berfokus untuk menilai kesiapan SVLK melalui 5 indikator utama yakni pemerataan 
implementasi SVLK untuk seluruh pelaku usaha, kapasitas pemerintah dalam mengimplementasikan SVLK, kelayakan SVLK sebagai standar legalitas di mata internasional, kompatilibitas SVLK dengan program lingkungan lainnya (REDD + dan Climate Change Program) serta hadirnya program-program kehutanan yang dipersiapkan oleh program multipihak. Secara umum, hasil evaluasi menyatakan bahwa program legalitas kayu pemerintah Indonesia melalui SVLK telah memenuhi ekspektasi dan secara efektif telah membantu mendukung pembangunan dan implementasi sebuah sistem verifikasi kayu (Multistakeholder Forestry, 2014). Meski demikian, hasil evaluasi memberikan catatan khusus pada indikator yang pertama terkait dengan pemerataan implementasi.Para ahli dan konsultan menjumpai bahwa lisensi V - Legal di Indonesia mayoritas hanya dimiliki oleh perusahaan menengah ke atas sedangkan pelaku usaha kecil secara umum belum memiliki izin dan oleh karenanya berpotensi untuk tidak dapat melakukan kegiatan ekspor (Multi-stakeholder Forestry, 2014). Salah satu faktor yang membuat terjadinya ketimpangan implementasi berbasis level usaha adalah tingginya biaya pengurusan SVLK yang kemudian membuat pelaku usaha bidang perkayuan pada level Industri Kecil dan Menengah (IKM) memutuskan untuk tidak mengurus izin (Brilliantono, 2013).

Menyambut hasil evaluasi terhadap SVLK, pemerintah Indonesia kemudian kembali melakukan upaya agar isu dan kelemahan yang dikemukakan dapat diatasi.Kementerian Kehutanan oleh karenanya membuat revisi yang ketiga terhadap Permenhut P.38 dengan mengeluarkan Permenhut Nomor P.42/ Menhut - II/2013 pada bulan Agustus 2013.Dalam Permenhut yang baru ini, pelaku bidang usaha kayu kelas menengah ke bawah boleh mengajukan permintaan legalisasi secara berkelompok (group certification) (Pasal 1 ayat 2). Permenhut P.42 merupakan revisi terakhir SVLK sebelum VPA ditandatangani.Pada tanggal September tahun 2013, VPA akhirnya resmi disepakati oleh pemerintah Indonesia dan UE di Brussells.Penandatangan dilakukan oleh Menteri Kehutanan Zulkifli Hasan serta pihak UE yang diwakili oleh Komisioner Eropa Bidang Lingkungan Janez Potocnik serta Menteri Lingkungan Hidup Lithuania Valentinas Mazuronis yang mewakili Lithuania sebagai Presidensi Uni Eropa.

Berdasarkan pemaparan di atas, dapat dipahami bahwa UE memiliki kontribusi yang signifikan dalam mempengaruhi arah penyusunan regulasi SVLK. Pandangan yang menyatakan bahwa pembangunan TLAS negara mitra diserahkan pada pemerintah nasional masing-masing negara mitra belum sepenuhnya terbukti, setidaknya pada kasus Indonesia. Dalam penyusunan SVLK sebagai TLAS untuk kerjasama VPA, penelitian ini menjumpai bahwa UE masih berperan dalam menentukan arah dan standar SVLK sebelum dapat diterima menjadi basis regulasi dalam VPA.Meski tentu saja tidak semua komponen SVLK disusun oleh UE namun menyatakan bahwa SVLK merupakan sebuah produk TLAS yang bebas intervensi UE sesungguuhnya merupakan sebuah pandangan yang kurang tepat.

Selain menjadi aktor yang mendorong pengimplementasian SVLK, UE juga berperan dalam mengarahkan dan mempengaruhi konten dan regulasi SVLK agar dapat mengikuti standar dan ekspektasi UE.Tercatat sejak tahun 2007 hingga tahun 2013, terdapat berbagai pertemuan antar delegasi UE dan Indonesia yang dikemas dalam berbagai forum untuk membahas dan merevisi SVLK. Pertemuan ini antara lain terdiri dari tiga Senior Official Meeting (SOM), tujuh Technical Working Group (TWG) dan tujuh Joint Expert Meeting (JEM) yang kesemuanya bertujuan untuk terus memperbaiki standar dan kualitas SVLK.

Esensi SVLK sebagai sebuah produk hasil 'intervensi' tercermin dari rangkaian kerjasama tersebut di atas yang memang bertujuan untuk menyempurnakan SVLK agar dapat menjadi TLAS yang ideal untuk VPA. Dari satu sisi, pemerintah Indonesia diberi kewenangan untuk merumuskan dan mengajukan SVLK tetapi di sisi lain, SVLK ini harus menjadi regulasi yang ideal mengikuti standar UE sebelum kerjasama VPA dapat disepakati. Desain 
kerangka kerjasama yang demikian kemudian secara sistematis mengarahkan proses perumusan regulasi dan konten SVLK mengikuti standar UE. Pertemuanpertemuan tersebut di atas kemudian dapat dipandang sebagai instrumen bagi UE untuk menanamkan pengaruh dan preferensi mereka terhadap desain regulasi SVLK.

Beberapa manifestasi nyata terhadap pengaruh dan preferensi UE dapat dilihat pada beberapa revisi SVLK yang dilakukan untuk mengakomodasi masukan dan standar yang diminta oleh UE dalam beberapa pertemuan-pertemuan yang telah disebutkan di atas. Seperti misalnya pada JEM yang berlangsung pada bulan September tahun 2009 dan bulan Mei tahun 2010 yang membahas mengenai kompatibilitas SVLK sebagai TLAS serta TWG masing-masing pada bulan Desember 2009, Maret dan Juni 2010 yang berfokus pada diskusi mengenai kesiapan SVLK menjadi TLAS yang efektif. Pada pertemuan-pertemuan ini pihak UE memberikan catatan khusus pada beberapa aspek SVLK yang dianggap belum maksimal khususnya pada aspek definisi serta mekanisme legalitas serta sistem verifikasi dan pemberian lisensi. Masukan dari UE ini kemudian diakomodasi melalui revisi SVLK yang pertama pada bulan Desember 2011 melalui Permenhut Nomor P.68/Menhut-II/2011yang mempertegas aspek definisi legalitas dengan menambahkan konten mengenai klasifikasi subjek regulasi dan mekanisme pemantauan. Terlihat bahwa revisi ini memiliki keterkaitan langsung dengan ekspektasi UE untuk memiliki TLAS dengan definisi legalitas yang tegas.Revisi pertama pada tahun 2011 menjawab ekspektasi tersebut dengan menghadirkan konsep legalitas yang lebih jelas.

Ekspektasi UE lainnya pada aspek verifikasi dan pemberian lisensi diakomodasi pada revisi SVLK yang kedua pada bulan Desember tahun 2012. Hal ini tercermin dari konten revisi SVLK ini yang akhirnya mengatur mengenai penggunaan tanda dan dokumen V-Legal sebagai identitas resmi kayu dan produk kayu legal yang telah melalui seluruh proses verifikasi dan memperoleh lisensi resmi dari otoritas Indonesia. Tanda dan dokumen V-Legal merupakan identitas legalitas sementara yang diberikan untuk menggantikan FLEGT - license yang dipersiapkan menjadi identitas legalitas resmi yang berlaku di bawah kerjasama VPA. Namun karena kerjasama VPA belum disepakati pada tahun 2012, maka identitas legalitas sementara yang diberikan kepada kayu dan produk kayu asal Indonesia yang akan diekspor ke Eropa adalah V-Legal. Kebijakan untuk mempercepat pemberian identitas legalitas ini secara khusus dilakukan untuk menyongsong regulasi EUTR yang mulai berlaku pada tahun 2013. Berlakunya EUTR akan mensyaratkan seluruh kayu dan produk kayu yang masuk ke wilayah UE memiliki dokumen penanda legalitas. Dari uraian di atas dapat dilihat bahwa UE memiliki kontribusi yang besar dalam mempengaruhi mekanisme lisensi atau pemberian izin legalitas kayu di Indonesia. Baik mekanisme lisensi yang sekarang melalui V-Legal maupun mekanisme FLEGT-license yang akan digunakan nanti setelah VPA disetujui merupakan metode yang berasal dari UE.

Selain V-Legal, konten revisi SVLK yang kedua juga mengatur pendirian institusi atau badan resmi terkait dengan pengaturan dan pemberian informasi mengenai proses verifikasi dan legalitas kayu di Indonesia. Institusi ini bernaung di bawah Direktorat Jenderal Bina Usaha Kehutanan, Kementerian Kehutanan dengan nama Sub-Direktorat Informasi Verifikasi Legalitas Kayu. Oleh karenanya, terlihat jelas bahwa revisi SVLK yang kedua ini merupakan jawaban terhadap ekspektasi UE terhadap mekanisme verifikasi dan pemberian lisensi.Terlihat bahwa revisi SVLK yang pertama dan kedua di tahun 2011 dan 2012 dilaksanakan untuk mengakomodasi beberapa poin dan ekspektasi dari UE yang belum dapat diwujudkan oleh SVLK generasi pertama dan oleh karenanya dapat dikatakan bahwa kebijakan untuk merevisi SVLK setidaknya hingga tahun 2012 sedikit banyak dipengaruhi oleh preferensi dan ekspektasi tertentu dari UE.

Revisi yang ketiga dilaksanakan pada bulan Agustus tahun 2013.Meski revisi kali ini tidak berkaitan langsung dengan preferensi ataupun ekspektasi khusus yang datang dari UE, namun lokakarya bersama 
dengan UE telah memberikan akses kepada pihak eksternal lainnya untuk ikut berkontribusi membangun konten SVLK. Sebagaimana norma dan prinsip umum yang dibangun oleh UE dalam menjalin kerjasama VPA, TLAS negara mitra harus dibangun secara terbuka oleh pemangku kepentingan yang datang dari beragam latar belakang. Prinsip ini kemudian memberikan kesempatan kepada berbagai aktor dapat ikut terlibat mengembangkan desain regulasi SVLK seperti pada keterlibatan dua LSM internasional yakni the European Forest Institute (EFI) dan Multi-stakeholderForestry Programme (MFP) yang menilai bahwa regulasi SVLK kurang berpihak pada IKM dan oleh karenanya perlu direvisi kembali. Revisi SVLK yang ketiga, meski tidak mengakomodasi langsung poin yang datang dari UE, merupakan kebijakan yang tidak dapat dilepaskan dari pengaruh UE.Dengan mengikuti prinsip keterbukaan dari UE, SVLK dapat memperoleh evaluasi dari pihak eksternal yang kemudian membuat revisi yang ketiga menjadi mungkin untuk dilaksanakan.

Secara umum dapat dikatakan bahwa UE memiliki peran yang cukup signifikan dalam menentukan arah dan konten penyusunan SVLK sebagai TLAS di Indonesia. Peran utama UE adalah membentuk SVLK agar dapat memiliki definisi legalitas yang lebih komprehensif. Hal ini wajar mengingat kepentingan utama UE dalam menginisiasi VPA adalah untuk memastikan bahwa kayu dan produk kayu yang diekspor ke pasar Eropa telah diperoleh dengan cara yang legal. Semakin komprehensif regulasi yang mengatur mengenai hal ini di negara mitra maka akan semakin kecil peluang produk ilegal untuk memasuki pasar Eropa yang berarti semakin terpenuhi pula kepentingan UE.

\section{KESIMPULAN}

Penelitian ini menyimpulkan bahwa Sistem Verifikasi Legalitas Kayu (SVLK) yang menjadi komponen utama VPA merupakan sebuah regulasi yang dikembangkan oleh pemerintah Indonesia yang juga mengakomodasi beberapa arahan dan ekspektasi dari UE. Oleh karenanya, penelitian ini berargumen bahwa UE memainkan peran yang cukup signifikan dalam pembangunan regulasi SVLK di Indonesia.

Selanjutnya, kebijakan VPA yang dibuat oleh UE semakin menegaskan pola pelaksanaan kebijakan luar negeri UE yang lebih banyak disandarkan pada konsep soft power yang diarahkan untuk kepentingan pemberdayaan dimensi eksternal (milieu goal) ketimbang memfokuskannya terbatas pada dialektika kepentingan nasional (possession goal). VPA merupakan sebuah instrumen UE untuk mengintervensi kebijakan ekspor kayu dan produk kayu negara-negara mitranya secara halus tanpa harus melakukan kebijakan yang lebih bersifat terbuka dan frontal. Hal yang lebih penting, dengan meminta negara mitra untuk mengaplikasikan VPA, UE secara tidak langsung berupaya untuk menaikkan standar regulasi perkayuan negara-negara ekportir kayu dengan memberikan kontribusi dan menanamkan pengaruh pada upaya penyusunan regulasi perkayuan nasional masing-masing negara. Pada kasus Indonesia, standar regulasi perkayuan Indonesia yakni SVLK coba diintervensi oleh UE melalui putaran negosiasi dan konsultasi. Hal ini sekaligus mempertegas kecenderungan politik luar negeri UE lainnya, yakni kecenderungan untuk bermain pada tataran normatif untuk mengubah dimensi eksternalnya agar dapat berada pada tataran level yang sama dengannya.

\section{CATATAN AKHIR}

Sebagai regulasi pengganti, konten peraturan pada UU Nomor 41 tahun 1999 tidak jauh berbeda dengan pendahulunya di tahun 1967. Fokus yang lebih komprehensif diberikan kepada aspek pemanfaatan hutan yang diatur pada Bab V mengenai Pengelolaan Hutan khususnya pada Pasal $23-40$.

2 Peraturan Pemerintah RI No. 34 tahun 2002 tentang Tata Hutan dan Penyusunan Rencana Pengelolaan Hutan, Pemanfaatan Hutan dan Penggunaan Kawasan Hutan, hal. 1.

\section{REFERENSI}

Bçrzel, Tanja A. "Foot-dragging and Fence-sitting: Member State Responses to Europeanization." Journal of Common Market Studies 40 (2002): 193 - 214.

Bçrzel, Tanja A. and Thomas Risse."Conceptualizing the Domestic Impact of Europe."In The Politics of Europeanization, edited by Kevin Featherstone and Claudio M. Radaelli. Oxford, Oxford University Press, 2003.

Clark, Julian and Alun Jones. "'Telling Stories about Politics: European- 
ization and the EU's Council Working." Journal of Common Market Studies 49 (2011): 341 - 66.

Esther Versluis, Mendeltje van Keulen dan Paul Stephenson. Analyzing the European Union Policy Process. New York: Palgrave Macmillan, 2010.

Featherstone, Kevin \& Claudio M. Radaelli, ed. The Politics of Europeanization. Oxford, Oxford University Press, 2003.

Flecthner, Stefanie. "European Security and Defense Policy: Between Offensive Defense and Human Security."International Policy Analysis Unit, Friedrich Ebert Stiftung (2006).

Fontana, Merie-Christine. "Europeanization and Domestic Policy Concertation: How Actors use Europe to Modify Domestic Patterns of Policy Making." Journal of European Public Policy 18 (2013): $654-71$.

Olsen, Johan P. "The Many Faces of Europeanization." Journal of Common Market Studies 40 (2002): 921-52.

Quaglia, Lucia et.al."Europeanization." in European Union Politics ( $2^{\text {nd }}$ Ed.), edited by Michelle Cini. Oxford, Oxford University Press, 2007.

Tarrow, Sydney. Power in Movement: Social Movements and Contentious Politics." Cambridge: Cambridge University Press, 1994.

Laidi, Zaki. "European Preferences and their Reception."In EU Foreign Policy in a Globalized World, edited by Zaki Laidi. New York: Routledge, 2008.

Nielsen, Kristian L. "EU Soft Power and the Capability-Expectations Gap."Journal of Contemporary European Research 9 (2013): 723 $-39$.

Nye, Joseph. The Means to Success in World Politics. New York: Public Affairs, 2004.

Smith, Karen E. European Union Foreign Policy in a Changing World. Cambridge: Polity Press, 2003. 